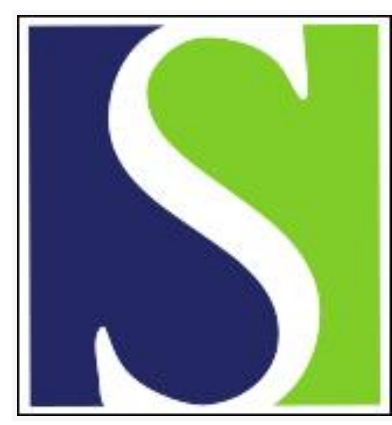

Scand J Work Environ Health 2009;35(5):334-341

https://doi.org/10.5271/sjweh.1346

Published online: 25 Aug 2009, Issue date: 00 Oct 2009

Trends in sickness absence in Denmark

by Johansen K, Bihrmann B, Mikkelsen S, Lynge E

Affiliation: University of Copenhagen, Institute of Public Health, Østerfarimagsgade 5, opg B, Postboks 2099, 1014 Copenhagen K, Denmark. k.johansen@pubhealth.ku.dk

The following articles refer to this text: 2010;36(1):34-41;

2010;36(6):515-516; 2014;40(4):361-369

Key terms: Denmark; sickness absence; sickness absence incidence; time trend; trend

This article in PubMed: www.ncbi.nlm.nih.gov/pubmed/19705042 


\title{
Trends in sickness absence in Denmark
}

\author{
by Kristina Johansen, MA, ${ }^{1}$ Kristine Bihrmann, MSc, ${ }^{1}$ Sigurd Mikkelsen, MD, ${ }^{2}$ Elsebeth Lynge, PhD ${ }^{1}$
}

\author{
Johansen K, Bihrmann K, Mikkelsen S, Lynge E. Trends in sickness absence in Denmark. Scand J Work Environ \\ Health. 2009;35(5):334-341.
}

Objective Based on the prevailing view that it has become a more common behavior, sickness absence is presently a topic of considerable concern in many European countries. Using sickness absence data from Denmark, we aimed to show whether this assumption holds true or not.

Methods We used a linear regression analysis to analyze time trends in sickness absence based on datasets from the Confederation of Danish Employers, the State Employer's Authority, the Labor Force Survey, and Statistics Denmark.

Results The findings from the Confederation of Danish Employers, the State Employer's Authority, and the Labor Force Survey indicated a stable and largely unaltered pattern of sickness absence during the last 20 years. Findings from Statistics Denmark showed an increase in the cumulative incidence proportion from $6.6 \%$ to $7.5 \%$ among employed people between 2000 and 2007.

Conclusion Our data did not indicate that sickness absence behavior has become more common in Denmark during the past 20 years; although, an increase was seen in the beginning of this century. It is apparent that the many reports on sickness absence that highlight an increasing trend are based on sickness benefit reimbursement data and have overlooked the underlying changes over time in the risk population and the entitlement to reimbursement.

Key terms sickness absence incidence; time trend.

Sickness absence has received considerable scientific and political attention in recent years in many European countries (1-4). Scientifically this has led to a new emphasis on individual and structural determinants of sickness absence, and large-scale cohort studies have been set up (5-7).

In the Netherlands, the sickness absence rate has been above that of other European countries causing concern at governmental level, resulting in the privatization of the sickness insurance and a growing emphasis on workplace-oriented preventive activities (8-10). In Sweden, an increase in registered sickness absence since the late 1990s has caused great concern; in 2003, the Swedish Council of Technology Assessment in Healthcare published an extensive review of the literature on sickness absence (11). The previous Swedish government had the ambition of reducing sickness absence by $50 \%$ in the period 2002-2008; the discussion of sickness absence remained on the political agenda and was further highlighted during the 2006 parliamentary election campaign. In Norway, reduction of the high sickness absence rate has been a political issue since the early 1990s culminating with the "Inclusive Working Life Agreement" aimed at reducing sickness absence by $20 \%$ from 2001 to 2009 , increasing the focus on job presence, and avoiding exclusion from the labor market $(12,13)$.

In Denmark, concern about the level of sickness absence has also been growing in recent years, more research has been initiated focusing especially on the work environment, and recently the Danish government initiated a major plan called "Sickness Absence - a Shared Challenge" comprising 30 initiatives aimed at reducing levels of sickness absence (14). The present aim of the Danish government is to reduce sickness absence by $20 \%$ by 2015 .

It seems to be a prevailing view in many countries that sickness absence has increased to an unprecedentedly

1 University of Copenhagen, Institute of Public Health, Copenhagen, Denmark.

2 Department of Occupational Medicine, Copenhagen University Hospital, Glostrup, Denmark.

Correspondence and reprints to: Kristina Johansen, University of Copenhagen, Institute of Public Health, Østerfarimagsgade 5, opg B, Postboks 2099, 1014 Copenhagen K, Denmark. [E-mail: k.johansen@pubhealth.ku.dk] 
high level, and that political initiatives for control are warranted; as the Organization for Economic Cooperation and Development (OECD) stated in a recent report, "there is now an urgent need to address the medicalization of the labour market problems" (15).

In Denmark, reimbursement of sickness absence has been registered by Statistics Denmark (Danmarks Statistik) since 1974. These data show a picture of considerable fluctuation over time (figure 1), but since 1992 there has been an almost steady increase in reimbursements, and, in Denmark, this trend has no doubt contributed to the prevailing impression of a continued growth in sickness absence. The number of reimbursements reflects, however, the legislation that has changed over time (eg, qualifying days, length of employer period, and length of refundable period). The number of reimbursements are furthermore affected by the use of voluntary insurance among employers, and the proportion of employees exempted from the employer period, etc. (16). It is, therefore, not possible to identify correctly the risk population for the registered reimbursements.

However, the question as to whether there is an increasing "medicalization" of labor market problems in the sense that sickness absence is more common today than it was 10-20 years ago remains an important one. We, therefore, decided to provide the best possible answer to this question. Absence is, by definition, "absence from something", and valid studies on sickness absence therefore require data both on the numerator (number of absent persons) and the denominator (number of persons at risk). To make the study comprehensive, we included all Danish sickness absence data sets with information on both the numerator and denominator.

\section{Materials and methods}

\section{Data collection}

In Denmark, data on sickness absence with information on both the nominator and denominator were available from the Confederation of Danish Employers (Dansk Arbejdsgiverforening or DA), the State Employer's Authority (Personalestyrelsen), and the Labor Force

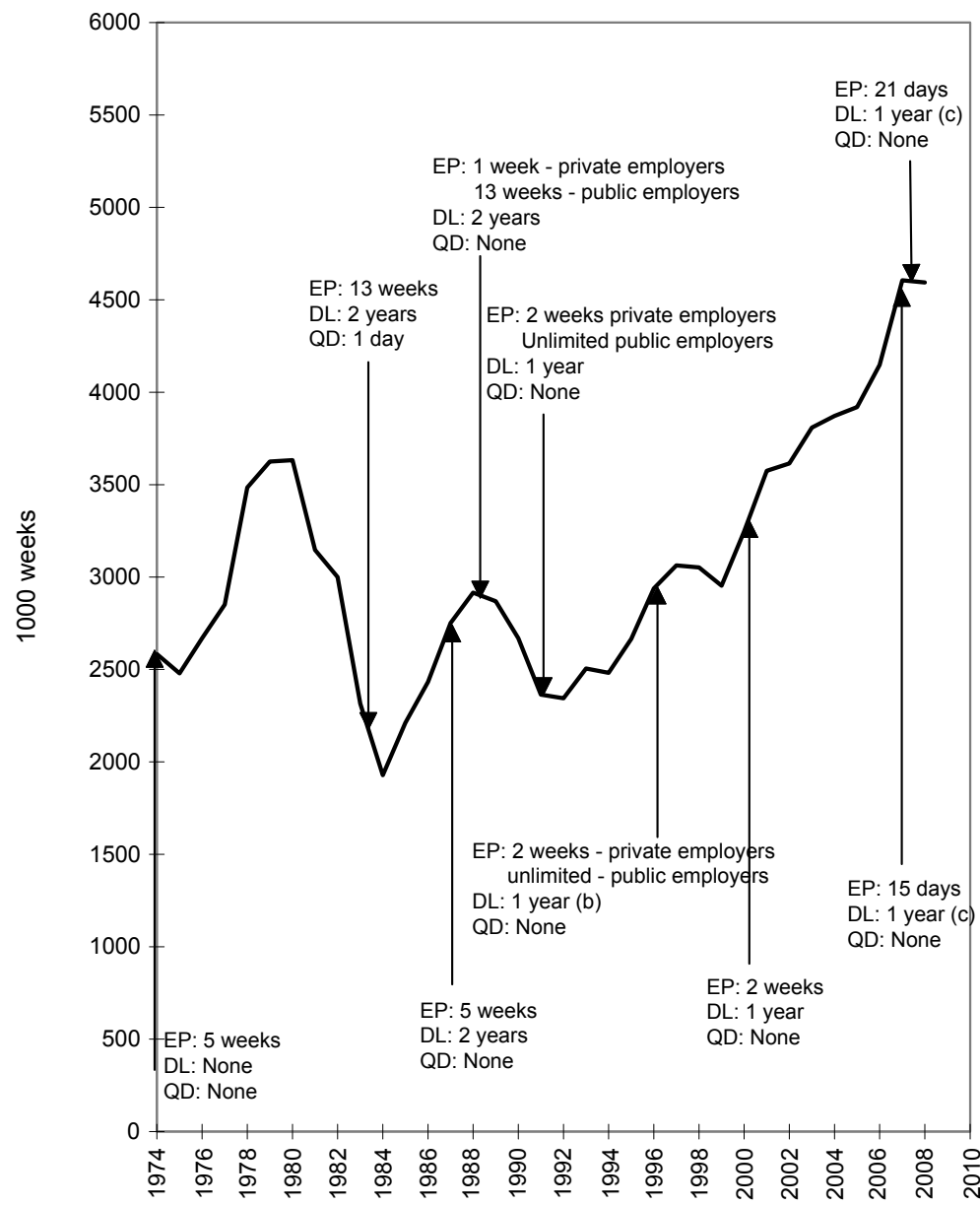

Figure 1. Source: Statistics Denmark. Number of weeks of sickness benefit reimbursement from municipalities per year and major changes in sickness benefit legislation. Benefit weeks is the only measure published for the entire period. If a person is applying for early retirement, payment of sickness benefit can be extended by 26 weeks beyond the duration limitation of 52 weeks. Payment of sickness benefit can be extended by an additional $2 \times 52$ weeks if a person is under medical treatment and he/she is

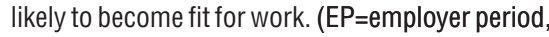
$\mathrm{DL}=$ duration limitation, $\mathrm{QD}=$ qualifying day) 
Survey (Arbejdskraftundersøgelsen); consequently, we used the sickness absence measures provided directly by these data sources. From Statistics Denmark, comparable data could be constructed from the raw data, but only for the period 2000-2007.

The DA has registered sickness absence in the private sector continuously since 1973 . The database covers employees in manufacturing, services, and building/ construction industries; the statistic is, therefore, not representative of the entire private sector. Moreover, small workplaces are underrepresented. All data are based on voluntary reporting. In 1973, the statistics covered 3700 enterprises and 197700 employees (147 100 bluecollar workers and 50600 white-collar workers) (17). In 2004, this had declined to 300 establishments and 46109 employees (18). In 2006, the database was enlarged by a stratified random sample of enterprises with at least 250 employees. The sample size currently covers approximately 1350 enterprises and 355000 employees. The sickness absence measure has been calculated as: sickness absence days as percent of calendar work days per year or per quarter. In 2006 , the calculation was slightly modified and is now calculated as: (sickness absence hours $\times 100$ ) / (performed hours + sickness absence hours). Performed hours do not include overtime, and it is assumed that a normal work day is 7.4 hours (19).

The State Employer's Authority has registered all sickness absence at government workplaces since 1984 . Every three months, employers at all government workplaces are obliged to report sickness absence for all employees. The statistics covered in 1984 and 2005, 210000 and 130000 employees, respectively $(20,21)$. After a process of privatization in the middle of the 1990s, part of the train and postal services were excluded from the statistics, therefore comparisons before and after 1995 must be subjected to reservations (22). The sickness absence rate is calculated as the average number of sickness absence days per employee per year. Before 2005, only whole sickness absence days were registered, but since 2005 hours and minutes have also been registered. The sickness absence measure is calculated annually as: (sickness absence standard days) / (employees in total).
The Labor Force Survey is a continuous interview survey designed to provide information on the Danish labor market following the international recommendations of the International Labour Organization. The Danish Labor Force Survey has been conducted annually since 1984; the Nordic Social-Statistical Committee has published the Labor Force Survey figures on sickness absence since 1990 (23). The Labor Force Survey measures sickness absence by asking a random sample of approximately 40000 persons whether they were absent from work due to own illness, injury, or temporary disability during the entire week prior to the interview. In 2007, the survey was reorganized and extended to 89000 persons. The dataset gives no information on sickness absence shorter than one week (24). Sickness absence measure is calculated as the number of persons absent from work due to illness as a percentage of all persons employed: (employees absent during one week $\times 100) /($ employees in total).

Statistics Denmark registers all sickness absence reimbursed by the municipalities. The registration is comprehensive as the system is mandatory and publicly financed. It is the same dataset that is included in the register-based Evaluation of Marginalization (the so-called DREAM database), which has been used for a number of recent sickness absence studies in Denmark $(25,26)$. While the legislation on reimbursement has changed considerably over time, for the period 2000-2007, the entitlement to sickness benefit for longer periods of illness (minimum two weeks) has not changed for employed persons. We therefore established the sickness absence trend for this very recent time period taking the size of the risk population into account. Based on individually linked records, we measured the cumulative incidence proportion for sickness absence in a calendar year calculated as: (incident cases) / (number of employed persons at risk at the beginning of the year). The incident cases were all persons in the denominator population starting at least one period of sickness absence in the given year. Table 1 summarizes the different available data sources and the methods used for presenting the data.

Table 1. Datasets on sickness absence in Denmark.

\begin{tabular}{|c|c|c|c|}
\hline Datasets & Coverage & Time period & Calculated sickness absence measure \\
\hline $\begin{array}{l}\text { 1. Confederation of Danish Employers } \\
\text { (Dansk Arbejdsgiverforening) }\end{array}$ & $\begin{array}{l}\text { Private sector (approximately } 200000 \text { employees } \\
\text { in } 1973 \text { and } 50000 \text { employees in 2006) }\end{array}$ & $1973-2007$ & $\begin{array}{l}\text { (Sickness absence hours } \times 100) /(\text { Performed } \\
\text { hours }+ \text { sickness absence hours) }\end{array}$ \\
\hline $\begin{array}{l}\text { 2. State Employer's Authority } \\
\text { (Personalestyrelsen) }\end{array}$ & $\begin{array}{l}\text { Government workplaces (approximately } 210000 \\
\text { employees in } 1985 \text { and } 130000 \text { in 2006) }\end{array}$ & 1984-2008 & $\begin{array}{l}\text { (Sickness absence standard days) / } \\
\text { (Employees in total) / (year) }\end{array}$ \\
\hline $\begin{array}{l}\text { 3. Labour Force Survey } \\
\text { (Arbejdskraftundersøgelsen }\end{array}$ & $\begin{array}{l}\text { Randomized sample of population approximately } \\
89000 \text { interviews pr year }\end{array}$ & 1984-2007 & $\begin{array}{l}\text { (Employees absent during one week } \times 100) / \\
(\text { Employees in total) }\end{array}$ \\
\hline $\begin{array}{l}\text { 4. Statistics Denmark (Danmarks } \\
\text { Statistik) }\end{array}$ & $\begin{array}{l}\text { All employed persons receiving sickness benefit } \\
\text { (176 } 640 \text { in } 2000 \text { and } 199785 \text { in 2007) }\end{array}$ & $2000-2007$ & $\begin{array}{l}\text { (Incident cases) / (number of employed } \\
\text { persons at risk at the beginning of the year) }\end{array}$ \\
\hline
\end{tabular}




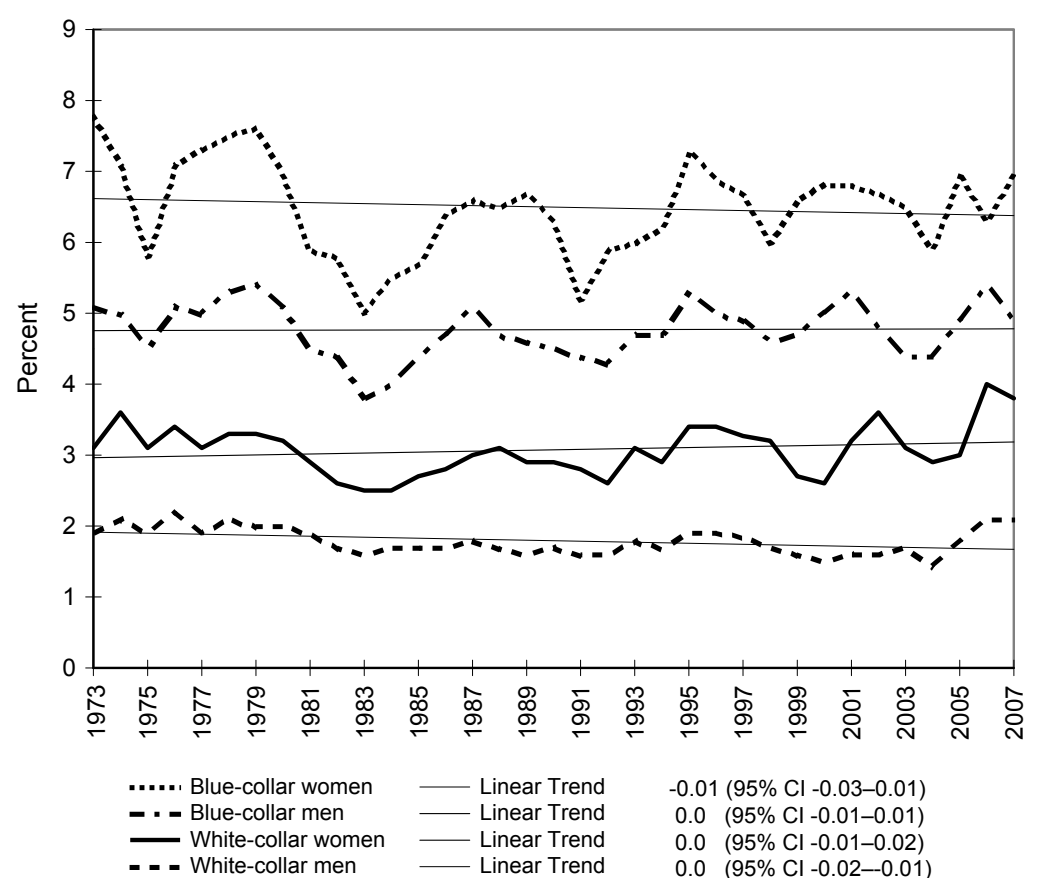

Figure 2. Source: The Confederation of Danish Employers (DA). Sickness absence days as percent of calendar work days. For the period 1973-1994, absenteeism was reported on a quarterly basis and measured as the percentage of calendar work days. In 1995, the statistics were rearranged and onwards only reported once a year, consequently, there was a break in data during 1995. In 2006, the statistics were enlarged with a representative sample of 1350 enterprises. Sickness absence due to work injury is included in the data.

\section{Analysis}

The ideal epidemiological measure of sickness absence as a human behavior is the incidence rate defined as: (the number of new sick-leave spells during the study period) / (the number of person-years at risk accumulated during the study period) (27). This measure could not be constructed from any of the available data sources; therefore, we had to base the analysis on other measures. The sickness absence measures used in the DA and State Employer's Authority were sickness days as proportions/averages of work days, while the Labor Force Survey recorded the sickness absence prevalence proportion. The sickness absence measure based on the Statistics Denmark 2000-2007 data was a cumulative incidence proportion, and thus the available measure closest to a sickness absence incidence rate.

We used a linear regression analysis to analyze the trend over time, with the sickness absence measure as the dependent variable and the year as the independent variable. However, most of the data derive from large subgroups of the Danish population, and variation over time is expected to reflect real variation rather than random fluctuation. Due to the inherent limitations of all the datasets, further breakdown of the data beyond the level presented by the data providers was achievable only for the Statistics Denmark 2000-2007 data.

\section{Results}

Figure 2 shows the data from the DA, which depicts a considerable variation in sickness absence across the four groups of employees in the private sector. The sickness absence percent is lower for men than women and lower for white-collar workers than their blue-collar counterparts. Female blue-collar workers have had a sickness absence of 6-7\%; male white-collar workers have had a sickness absence of approximately $2 \%$. The social gradient in the sickness absence has been very stable during the period. The linear regression analysis demonstrates an almost horizontal line for each of the four employee groups. The trend estimates being -0.007 [95\% confidence interval $(95 \% \mathrm{CI})-0.030-0.016]$ for blue-collar women, 0.001 (95\% CI -0.013-0.014) for blue-collar men, 0.006 (95\% CI -0.006-0.019) for white-collar women, and 0.007 (95\% CI -0.013- -0.001) for white-collar men, only the last two groups being significant.

Figure 3 depicts sickness absence data from the government workplaces covered by the State Employer's Authority data, the population sample covered by the Labor Force Survey, and the total employed population based on reimbursement of sickness benefit registered by Statistics Denmark. The State Employer's Authority and Labor Force Survey data sources confirm a stable pattern of sickness absence in the observed time period. The time series from government workplaces show that sickness absence in 1984 averaged 8.8 days per employee. The curve fell during the 1990s only to increase again since 2000, reaching an average of 9.0 sickness absence days in 2007, and decreasing slightly again in 2008 . The linear regression analysis estimates a slight downward trend $-0.057(95 \% \mathrm{CI}$ $-0.099-0.015$ ) (regression line not shown in figure 3 ), however, the temporary low level in 1995 and 1996 can be attributed to the partial privatization of the train and 


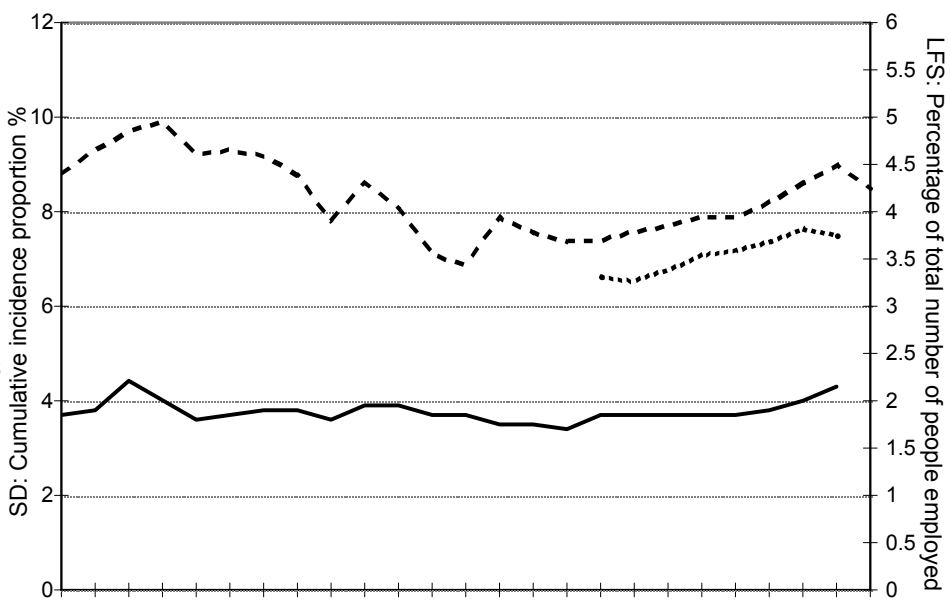

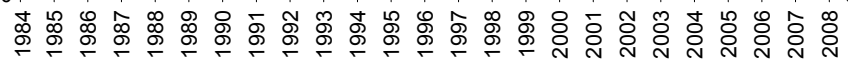

Figure 3. Source: State Employer's Authority (SEA), Statistic Denmark (SD), and Labor Force Survey (LFS). Average number of sickness absence days per year, cumulative incidence proportion and absence from work due to illness as percentage of all people employed. State Employer's Authority data include sickness absence due to work injury. Sickness absence from work for at least one week based on Labor Force Survey was calculated as the average of the survey in the year in question. Labor Force Survey data from 1984-1989 was provided by the library of Statistics Denmark. The presented Statistics Denmark data are based on authors' calculations. postal services, both workplaces with relatively high sickness absence rates (21). The sickness absence rate as measured in the Labor Force Survey varied around 2\% between 1984 and 2007. The linear regression analysis estimates an almost horizontal trend -0.002 (95\% CI -0.016- -0.013). Based on data from Statistics Denmark, the cumulative incidence proportion of sickness absence among employed persons increased from $6.6 \%$ to $7.5 \%$ in the period 2000-2007. The linear regression analysis estimates an increasing trend of 0.161 (95\% CI $0.114-0.207)$. The increase was mainly due to a growth in sick absence among women. Percentage-wise, the largest increase was in the age group 30-39 years. The increase in the cumulative incidence proportion in the relative short period from 2000 to 2007 is in line with the trend in State Employer's Authority and Labor Force Survey data sources; the linear regression estimate for the State Employer's Authority data in this short period is 0.211 (95\% CI 0.150-0.271). In 2007, sickness absence decreased slightly in the Statistics Denmark data, whereas a more marked decrease occurred in the State Employer's Authority data in 2008.

\section{Discussion}

All the datasets suffer from various shortcomings, such as changes over time in the registration methodology, thus making it difficult to draw conclusions on the time trend in sickness absence in Denmark. However, based on the data from the DA, the State Employer's Authority, and the Labor Force Survey, the sickness absence level in Denmark has varied between labor market groups, but the trend over time in each group seems to have remained fairly constant. Our calculations based on data from Statistics Denmark show an increase from $6.6 \%$ to $7.5 \%$ in the cumulative incidence proportion among employed people from 2000-2007. Due to recurring amendments of the legislation, it has only been possible to construct this epidemiological measure for a very short period of eight years. With the necessary reservations, the collective body of evidence does not indicate that sickness absence behavior has become more common in Denmark over the past 20 years, though some increase was noted in the beginning of this century. These results are surprising, taking into consideration the political attention that sickness absence has attracted in the public debate.

The sickness absence data from the DA have been widely used, as they constitute the most comprehensive time series including both short and long term absenteeism in the private sector (28-31). However, the accuracy of the data depends on the quality of the information collected by the employer. Moreover, the statistics are not representative of the entire sector; the fact that it is based on mainly larger enterprises voluntarily reporting indicates that one should interpret the data with some reservation, particularly as there is a strong assumption that sickness absence in the private sector is systematically underestimated (32).

Sickness absence data from the Labor Force Survey have been used for international comparisons, as these data cover a sample of the entire working population 
and the surveys have a similar design across Europe $(4,33)$. However, there are some limitations when using the Labor Force Survey. It was not designed to measure sickness absence (34), and the use of a reference week means that the Labor Force Survey can only measure sickness absence lasting at least seven days. By ignoring the short term sickness absence, these surveys clearly underestimate the overall absence rate. The data are self-reported and the validity of such data on sickness absence has been questioned in the literature (35). More importantly, at present $15 \%$ of the sample cannot be contacted because they have chosen the option in the Central Population Register law to refuse participation in surveys; the response rate of the remaining sample is only $63-68 \%$ in Denmark (24).

Fuelled by the ongoing discussion in the beginning of the 1980s on reintroducing a qualifying day for entitlement to sickness benefit, the State Employer's Authority began examining the issue of sickness absence more closely.

The registration of sickness absence from government workplaces is fairly complete; however, these workplaces represent a more selective group of people, dominated by white-collar workers, making it difficult to generalize the findings to the whole population. It is possible that the historically low unemployment rate in recent years can explain the slight increase in sickness absence after 2003 since sickness absence may correlate negatively with unemployment, mainly due to the recruitment of marginal workers with many and/or long sickness periods, and the disappearance of the disciplining effect of unemployment (36). On the rare occasions where a person is still employed after one year of sickness, some legislative changes may also affect these numbers.

The three datasets from the DA, the State Employer's Authority, and the Labor Force Survey all have limitations. However each dataset has a certain internal consistency. It is, therefore, reassuring that all three data sets indicated a fairly similar trend in sickness absence in Denmark over time.

The calculated cumulative incidence proportion based on Statistics Denmark data 2000-2007 show a slight increase in sickness absence in line with the trend in the State Employer's Authority data from the same period. The Statistics Denmark dataset is the most valid one, as it covers the entire population and the registration has not changed during the period except for an extension of the duration limitation in 2007, causing a longer duration of reimbursed benefit spells for a selected group of recipients. Due to legislative changes, it is unfortunately not possible to calculate the cumulative incidence proportion from the period before 2000 or the period after 2007.

Our results differ from the sickness absence trend data presented by Statbank Denmark (37), where the percentage of employed persons having received sickness benefit for more than two weeks is reported as a constant percentage of $10 \%$ for women and $7 \%$ for men throughout the period 2003-2007. The inclusion criteria used in the Statbank Denmark have, however, changed slightly over time, whereas we have used the same inclusion criteria for the entire period 2000-2007. The difference between the two calculations stresses the importance of using consistent definitions and inclusion criteria in statistics on time trends in sickness absence.

The cumulative incidence proportion will differ from the incidence rate in various ways. Firstly, the number of persons at risk of absence at the beginning of the year will differ from the person-years at risk during the year, as absent persons do not accumulate risk time during their absence, and some persons will leave the fixed cohort during the one year follow-up period due to disability, retirement, or death. Secondly, as we tabulate persons and not person-years at risk in the denominator, only one sickness spell per person per year is considered in the numerator of the cumulative incidence proportion calculation. Thirdly, newcomers to the labor market during the year are not included in this calculation.

Although desirable, it is difficult to quantify the potential impact of legislative, administrative, and business cycle changes on the time trend in sickness absence. In a document from 2005, the Danish Economic Council modeled the Statistics Denmark sickness benefit reimbursement data taking the following variables into account: (i) employer period for public and private employers, (ii) unemployment rate, (iii) duration limitation, (iv) employment rate, and (v) qualifying days. The modeling indicated that the adjusted number of full-year sickness benefit recipients from 2000-2003 increased by either 0 or $11 \%$, thus leaving only a small margin for real change (38). However, in this model, there was no adjustment for people employed in flex jobs, employees covered by private employers insurance in the employer period, and people exempted from the employer period.

In conclusion, our data did not indicate that sickness absence behavior has become more common in Denmark during the past 20 years; an increase was, however, seen in the beginning of this century. It is apparent that the many reports on sickness absence, which used the sickness benefit reimbursement data and deduced a steady increase in sickness absence $(39,40)$, have overlooked the underlying changes over time in the risk population and the entitlement to reimbursement.

It is interesting that over the last 25 years - starting with the intense debate on the qualifying day in the early 1980 s - there has been a considerable political focus on sickness absence, and the sickness benefit legislation in Denmark has been subjected to numerous changes. At the same time, the national data monitoring 
the developments in sickness absence have remained astonishingly poor. A new national statistics on sickness absence covering the entire labor market is now being developed in Denmark. The first full-blown statistic showed that, in 2006, employees in the municipal sector were, on average, absent from work due to sickness for 12.5 working days, in the government sector the figure was 8.3 days, and in the private sector 8.1 days. These figures exclude persons in subsidized jobs and sickness due to work injuries (32). Based on this preliminary data, it is estimated that short-term sickness absence (less than two weeks) account for half of the entire sickness absence (41).

\section{Acknowledgements}

This study was financially supported by the Danish Work Environment Fund and the Danish Research School of Public Health. Thanks to Bo Møller from Statistics Denmark for providing data.

\section{References}

1. Bloch FS, Prins R. Who returns to work and why?: a six country study on work incapacity and reintegration. London: Transaction Publishers; 2001.

2. Gimeno D, Benavides FG, Benach J, Amick BC III. Distribution of sickness absence in the European Union countries. Occup Environ Med. 2004;61(10):867-69.

3. Gründemann RWM. Preventing absenteeism at the workplace: European research report. Luxembourg: European Foundation for the Improvement of Living and Working Conditions; 1997.

4. Nyman K, Bergendorff S, Palmer E. Den svenska sjukan: sjukfrånvaron $\mathrm{i}$ åtta länder [The Swedish disease-sickness absence in eight countries]. Stockholm: Fritzes offentliga publikationer; 2002. Report to ECO (Ds 49).

5. Head J, Kivimäki M, Martikainen P, Vahtera J, Ferrie JE, Marmot MG. Influence of change in psychosocial work characteristics on sickness absence: The Whitehall II Study. J Epidemiol Community Health. 2006;60(1):55-61.

6. Lund T, Labriola M, Christensen KB, Bultmann U, Villadsen E. Physical work environment risk factors for long term sickness absence: prospective findings among a cohort of 5357 employees in Denmark. BMJ. 2006;332(7539):449-52.

7. Väänänen A, Kumpulainen R, Kevin MV, Ala-Mursula L, Kouvonen A, Kivimäki M, et al. Work-family characteristics as determinants of sickness absence: a large-scale cohort study of three occupational grades. J Occup Health Psychol. 2008;13(2):181-96.

8. Allegro JT, Veerman TJ. Sickness absence. In: Drenth PJD, Henk T, de Wolff CJ, editors. Handbook of work and organisational psychology. East Sussex (United Kingdom): Psychology Press; 1998.

9. Geurts S, Kompier M, Gründemann R. Curing the Dutch disease? Sickness absence and work disability in the Netherlands. Int Soc Secur Rev. 2000;53(4):79-103.

10. van Dijk FJ, Prins R. Occupational health care and work incapacity: recent developments in The Netherlands. Occup Med (Lond). 1995;45(3):159-66.

11. Swedish Council on Technology Assessment in Health Care. Sickness absence: causes, consequences, and physicians' sickness certification practice: a systematic literature review by the Swedish Council on Technology Assessment in Health Care (SBU). Scand J Public Health Suppl. 2004;63:3-263.

12. Norwegian Labour and Welfare Organisation. Om IA-avtalen [About IA agreement] [Internet]. Oslo: Norwegian Labour and Welfare Organisation [cited 14 December 2007]. Available from: http://www.nav.no/1073747561.cms

13. Wergeland E, Bruusgaard D. Er fraværsreduksjon en oppgave for leger? [Reduction of sick leave a task for physicians?] Tidsskr Nor Laegeforen. 2005;125(21):2984-7.

14. Ministry of Employment. Det gør vi med sygefraværet: regeringens handlingsplan [Measures to reduce sickness absence: the Government's Action Plan] [Internet]. Copenhagen: Ministry of Employment [cited 2007 June 27]. Available from: http:/www.bm.dk/graphics/Dokumenter/ Udgivelser/Danske\%20udgivelser/2003/sygefravaer/ handlingsplan_sygefravaer_dec_2003.pdf

15. Organisation for Economic Co-operation and Development (OECD). Sickness, disability and work: breaking the barriers: Norway, Poland and Switzerland; vol I. Paris: OECD; 2006.

16. Johansen K. Controlling sickness absence: a study of changes in the Danish sickness absence legislation since 1973. Health Policy. 2008;86(1):109-18.

17. Confederation of Danish Employers. Statistikken, Arbejderløn: DA's lønstatistik [Danish Employers Confederation's Statistics on wages and salaries]. Copenhagen: Danish Employers Confederation; 1973.

18. Confederation of Danish Employers. Fraværsstatistik: DA's lønstatistik [Absenteeism statistics]. Copenhagen: Danish Employers Confederation; 2005.

19. Confederation of Danish Employers. Fraværsstatistik - Dokumentation: DA's lønstatistik [Absenteeism statistics - Documentation] [Internet]. Copenhagen: Danish Employers Confederation [cited 22 October 2008]; Available from: http://www.da.dk/bilag/Frav\%E6rsStatistik\%20\%20dokumentation\%2012-09-08.pdf

20. State Employer's Authority. Nøgletal om fravær for ministerområder i 2005 [Key figures on absenteeism in ministries 2005] [Internet]. State Employer's Authority [cited 2009 August 20]. Available from: http://www.integration-istaten.dk/db/filarkiv/12973/Fravaer_paragraf_2005.pdf

21. Ministry of Finance. Vejledning om sygefravær [Guidance on sickness absence]. Copenhagen: Ministry of Finance; 1991.

22. Danish Agency for Governmental Management. Fravær i staten: løn og personale statistik [Absenteeism at government 
workplaces]. Copenhagen: Danish Agency for Governmental Management; 1996.

23. Nordisk Socialstatistiks komité (NOSOSCO). Social Protection in the Nordic countries: scope, expenditure and financing. Copenhagen: NOSOSCO; 1996.

24. Statistics Denmark. Declarations of content: Labour Force Survey [Internet]. Statistics Denmark [cited 14 December 2007]. Available from: http://www.dst.dk/HomeUK/ Guide/documentation/Varedeklarationer/emnegruppe/emne. aspx?sysrid $=0857$

25. Hjollund NH, Larsen FB, Andersen JH. Register-based followup of social benefits and other transfer payments: accuracy and degree of completeness in a Danish interdepartmental administrative database compared with a population-based survey. Scand J Public Health. 2007;35(5):497-502.

26. Lund T, Kivimäki M, Labriola M, Villadsen E, Christensen KB. Using administrative sickness absence data as a marker of future disability pension: the prospective DREAM study of Danish private sector employees. Occup Environ Med. 2008;65(1):28-31.

27. Hensing G, Alexanderson K, Allebeck P, Bjurulf P. How to measure sickness absence?: literature review and suggestion of five basic measures. Scand J Soc Med. 1998;26(2):133-44.

28. Bovin B, Wandall J. Sygedage: fravær blandt ansatte i amter og kommuner [Sick days: absenteeism among employees in counties and municipalities]. Copenhagen: AKF Forlaget; 1989.

29. Holm K, Hummelgaard H, Mikkelsen P, Rieper O. Sygefravær og karensdag [Sickness absence and qualifying day]. Copenhagen: AKFs Forlag; 1986.

30. Rosdahl A, Due J. Omfanget af ledighed og sygefravær [Extent of unemployment and sickness absence]. Copenhagen: Danish National Institute of Social Research; 1980.

31. Sundbo J. Arbejdsfravær [Absence from work]. Copenhagen: Danish National Institute of Social Research; 1982.

32. Statistics Denmark. Arbejdsmarked: fraværsstatistik [Labour market: statistics on absence]. Copenhagen: Statistics Denmark; 2008.
33. Barmby TA, Ercolani MG, Treble JG. Sickness absence: an international comparison. Econ J. 2002;112(480):315-31.

34. Barham C, Leonard J. Trends and sources of data on sickness absence. Labour Market Trends. 2002;110(4):177-85.

35. van Poppel MN, de Vet H, Koes B, Smid T, Bouter LM. Measuring sick leave: a comparison of self-reported data on sick leave and data from company records. Occup Med. 2002; 52:485-90.

36. Arai M, Thoursie PS. Incentives and selection in cyclical absenteeism. Labour Econ. 2005; 12(2):269-280.

37. Statistics Denmark. SOCDAG2: recipients of sickness benefit at longer time illness compared to total number of employed (2003-2008) [Internet]. Copenhagen: Statistics Denmark [cited 11 June 9 A.D.]. Available from: http://www.statistikbanken. $\mathrm{dk} /$ statbank $5 \mathrm{a} /$ default.asp? $\mathrm{w}=1680$

38. Economic Council. Betydningen af konjunktur og regelændringer for udviklingen i sygedagpengemodtagere: baggrundsnotat vedrørende Dansk Økonomi, forår 2005 [Influence of business cycle changes and changes in legislation for the development in sickness benefit recipients: working document] [Internet]. Copenhagen: Economic Council [cited 16 July 2008]. Available from: http://www.dors.dk/sw1634.asp

39. Ministry of Employment. Analyse af det danske sygefravær [Analysis of the Danish sickness absenteeism] [Internet]. Copenhagen: Ministry of Employment [cited 14 December 2007]. Available from: http://www.bm.dk/graphics/ dokumenter/presse $\% 200 \mathrm{o} \% 20$ nyheder/arrangementer/ sygefravaer/030506/analyserapport.pdf

40. Ministry of Employment. Analyse af sygefraværet [Analysis of sickness absenteeism] [Internet]. Copenhagen: Ministry of Employment [cited July 18 2008]. Available from: http://www. bm.dk/sw25973.asp

41. Statistics Denmark. Dagpenge ved sygdom 2005 [Benefit due to sickness 2005]. Copenhagen: Statistics Denmark; 2006.

Received for publication: 23 June 2009 